\section{Endonasal approach}

昭和大学脳神経外科

阿部 琢巳，松本 清

下垂体腫瘍に対する endonasal approach は欧米諸国では一 般に施行されている手技であるが，鼻が低く鼻孔が丸い日本 人においては十分な術野が得られないなどの理由から不向き であると言われてきた。私はハンブルグ大学 Dr. Luedecke のもとで約 2 年間 endonasal surgeryを学んできた経験か ら, 経鼻手術専用器具を用いて決められた方法に従って行え ば，何ら問題なく施行できると確信している．今回はわれわ れの行っている下垂体腫瘍に対する endonasal surgery を紹 介する.われわれはLuedeckeの経鼻手術専用器具（Waldemar Link, Hamburg) を用いている. 最も有力な器具は micro-pressure-suction-irrigation system (MPSIS) であ り，これは限られた狭い術野内で片手で洗浄と吸引が同時に 施行できる利点をもつ. 手術は左前鼻孔を用い鼻中隔軟骨前 縁に沿って逆 J 字型の切開を加える. 鼻中隔軟骨膜を軟骨実 質から剥離し鼻孔の大きさに応じた speculum を挿入する。 蝶形骨洞前壁・トルコ鞍底は弱彎の high speed drill (Midas Rex) にて削除する。鞍内の腫瘍をMPSISで洗 浄・吸引・摘出後, micromirror を用いて鞍上部前方部や 海綿静脈洞浸潤部の腫揚を直視下に摘出する. MPSIS だけ では摘出困難な硬い腫瘍はニードルタイプの超音波手術装置 (Olympus）を用いて摘出している.

\section{2. 経鼻孔経蝶形洞内視鏡手術における工夫と進歩 山形大学脳神経外科$$
\text { 黑木 亮, 嘉山 孝正 }
$$

目的 下垂体腫瘍などのトルコ鞍部病変に対する内視鏡単 独での経鼻孔手術におけるわれわれの工夫について報告す る.

方法 対象は，内視鏡支援顕微鏡手術例を除き内視鏡のみ で手術を行ったトルコ鞍部病変 36 例. 外径 $4 \mathrm{~mm}$, 先端角 $0^{\circ}$ の硬性鏡を主に，先端角 $30^{\circ}$ や $70^{\circ}$ の硬性鏡も使用し，3 D-CT virtual navigation にて鼻孔からトルコ鞍の形状を詳 細に検討した上で，基本的には一側鼻孔から鞍底に至り手術 を行った。

結果・考察 Virtual navigation像によって術中X線透視 を使用せずに conchal type sphenoid sinus例でも正確に drill で削開して鞍底の硬膜を露出できた，先端角 $30^{\circ}, 70^{\circ}$ の硬性鏡で側方や上方の腫㒵も直視下に摘出し得た。鞍外進 展の少ない下垂体腫瘍では全摘し，海綿静脈洞浸潤や鞍上進 展の顕著な例やラトケ囊胞などでは部分摘出を行った。専用 手術器械を開発し内視鏡を固定して両手での手術操作ができ た. 曇りや污れのない内視鏡像を得るいくつかの工夫を行っ て従来の顕微鏡手術に遜色のない映像と結果を得た。内視鏡 手術は, 視野が広く鞍底近傍の構造が把握しやすい上に, 術 後口腔内違和感や痛みがなく美観上も低侵襲であるなどの利 点があり，ナビゲーションの併用や手術器械のさらなる改良 などによってさらに進歩するものと考えられる．以上のこと を紹介すると共に手術の実際をビデオで供覧する。

\section{3. 経鼻的手術：endonasal vs sublabial approach}

福井医科大学脳神経外科 久保田紀彦

下垂体部病変に対する経鼻孔手術 (Endonasal Approach；EA）は，鼻孔が小さな日本人には，敬遠され がちな手技である。しかし，手術操作や器具を工夫すれば, ほとんどの症例に応用でき, Sublabial Approach (SA) に 比べ,いくつかの利点がある。これまでの 190 例の SA, 60 例の $\mathrm{EA}$ の経験を呈示する.私は, 直径 $40 \mathrm{~mm}$ 以上の大き な下垂体腺腫や大きな斜台部病変以外には, 全例に EA を選 択している.

EA は SA に比べ, 開創部がわずかで出血量が少なく, 短 時間で手術できる.SAにみられる術後の上口唇の腫れ, 歯 肉の知覚異常や感染は EA では皆無で, 術後 1 日目から提食 可能である，EAによる鼻孔の変形はない。手術手技は，ま ず，右鼻孔内側を半月状に切開し，内側下斜めにも切開を加 之, 前鼻棘, 右梨状孔を完全に露出し, 鼻中隔下端を分離 し, 蝶形骨洞前面に到達する。まず，小さな Nasal Speculum (Kubota Modified) を挿入し, 鼻孔が拡大した 時点で, 大きな Speculum に変えると, 視野はSA と同じで ある. EA では, 顕微鏡下の手術操作は SA と同じだが, 内 視鏡併用の腫瘍摘出が SAよりも困難である.

\section{Transtuberculum sellae approach \\ 北海道大学脳神経外科 \\ (現：函館中央病院脳神経外科) \\ 加藤 功}

目的 鞍隔膜上部腫瘍に対して，通常の transsphenoidal approach で到達することは難しい，そこでこの方法にわず かな工夫を加えることによって到達可能となり，transsphenoidal-transtuberculum sellae approach と称して行っ ているので紹介する.

方法・結果 トルコ鞍底部開空後，鞍結節から一部蝶形骨 平面の骨を削除することにより，前頭蓋底部硬膜の露出が約 $1 \mathrm{~cm}$ 可能となる。この硬膜を切開すると視交叉，下垂体柄 および腫瘍が直視下に観察できる。この方法をこれまで 17 症例（頭蓋咽頭腫 2, ラトケ囊胞 6 , 下垂体腺腫 7, 奇形腫 1, 下垂体柄部への転移性腫瘍 1）に行い，良好な結果が得 られている. なお術後の合併症としては，2例で一過性尿崩 症を呈した以外, 髄液漏や下垂体機能障害の悪化を認めた症 例はなかった。

結論 transsphenoidal-transtuberculum sellae approach は, 通常の transsphenoidal approachにて到達が難しい鞍 隔膜上部腫瘍や下垂体窩から鞍結節上方に進展した腫瘍に対 して有効な方法である。 